This is an Accepted Manuscript of an article published by Taylor \& Francis Group in Children's Geographies on 17 Jun 2019, available online:

http://www.tandfonline.com/10.1080/14733285.2019.1630716

\title{
Why have Generational Orderings been Marginalised in the Social Sciences including Childhood Studies?
}

\author{
Professor Samantha Punch - s.v.punch@stir.ac.uk
}

Faculty of Social Sciences, University of Stirling

\begin{abstract}
This paper considers why age and generation tend not to be recognised as social variables in the same way that gender, ethnicity and class are mainstreamed within Social Science disciplines. It questions why the concept of the generational order is not always integral to either Childhood Studies or the related sub-disciplines, such as Children's Geographies. It begins from a starting point that Childhood Studies is generally a multi-disciplinary field but seems stuck from moving forward conceptually. The politics of Childhood Studies can result in sub-disciplinary silos rather than working in a more interdisciplinary way. The politics of childhood in society have progressed in terms of children's rights and participation yet the theoretical development of children's agency has been stuck. The paper discusses the lack of extensive empirical investigation of the generational order, suggesting that 'generational orderings' may be a more dynamic way to engage with processes of generationing.
\end{abstract}

\section{Introduction}

This paper questions why the generational order is not always integral to Childhood Studies and how this may have hindered the mainstreaming of age and generation within the Social Sciences. The issues discussed here emerge from, and build on, recent work in Childhood Studies that calls for more interdisciplinary, cross-world dialogue that bridges the divide between academia and practice (Alanen et al., 2018; Cook et al., 2018; Punch, 2016a). The terms 'Majority World' and 'Minority World' are used as they appropriately reminds us that the more common global experience of childhood is that of the economically poorer continents (Asia, Africa and Latin America). In the Majority World children are more likely to combine work, school and play compared with the more privileged focus on play and school in the Minority World (Punch, 2003).

Despite there being many empirical studies of childhoods in the Minority World and separate studies exploring Majority World childhoods, the two literatures have tended to emerge separately rather than benefiting from learning across cultural contexts. There is some literature that draws on empirical studies from both world contexts, such as Children and Young People's Relationships (Punch and Tisdall, 2014) and Global Perspectives on Rural Childhood \& Youth (Panelli et al., 2007). The latter also has several thematic chapters which consider the key concepts of power, agency and identity across Majority and Minority World settings. However, such cross-learning opportunities are still uncommon, such as Jeffrey and Dyson's (2008) collection on Telling Young Lives and Chawla's (2002) collaborative work on Growing Up in an Urbanising World. Direct comparisons of childhoods located in the Majority World with those from a Minority World context are particularly scarce (for example, Cribari-Assali, 2018; Phoenix et al., 2017). Cindi Katz's work in the US and Sudan explored some of the "unexpected connections among disparate places" (2004, p. xiv). However, that comparison emerged after the second study was carried out, rather than being designed initially as a comparative study of changing childhoods. Thus, in practice the literatures of Majority and Minority World childhoods tend to remain separate apart from a few recent exceptions (see Punch, 2016a; Punch and Tisdall, 2012). 
This paper reflects on how these issues relate to some of the bigger questions of Childhood Studies in terms of conceptual and theoretical development. It started as the 'new sociology of childhood' in the late 1980s, becoming known as the 'social studies of childhood' in the 1990s when Children's Geographies also emerged. Now, approximately 30 years since it began, the broader field is more commonly referred to as 'Childhood Studies'. Thus, whilst this paper is clearly linked to the sub-field of the Geographies of Children and Youth, it will tend to refer to the umbrella term 'Childhood Studies' which includes various social science sub-fields that relate to childhood, including sociology and anthropology. There have been a range of successes in the past three decades as a community of childhood researchers and a new field were established with a variety of organisational enterprises, projects and networks (Cook et al., 2018) as well as specialist degrees and modules at undergraduate, masters and doctoral level. Yet there have been ongoing challenges and more might have been achieved as Childhood Studies tends to be stuck in relation to various issues, and this paper considers why that might be the case.

\section{Politics of Childhood Studies}

A question for Childhood Studies is why age and generation are not mainstreamed within key disciplinary areas, such as within Geography or Sociology. Huijsmans (2016: 2) argues that Childhood and Youth Studies have only had a marginal impact on Development Studies, and that "development studies and practice have remained adult-centric". Why are age or generation not key social variables in the same way that gender, class, ethnicity and disability are recognised? For example, sometimes when childhood researchers submit a paper to mainstream sociological journals, it may be returned without being sent on to reviewers, with the advice that there are specialist journals (Children's Geographies; Childhood; Children \& Society; Global Studies of Childhood) that are better suited for a discussion of childhood-related issues. This is partly because age has become recognised as an important social variable within the sub-disciplines of Childhood Studies but not more broadly outside of the field:

$\ldots$ if the body of knowledge in general sociology remains ignorant of generational ordering as a distinct organizing principle of social relations, the social study of childhood is at risk of remaining isolated from the main areas of social research. (Alanen, 2009: 171).

Over the past three decades childhood researchers have worked hard to establish Childhood Studies as a field in its own right (James et al., 1990; Mayall, 2002) but age continues to be on the margins of mother disciplines. Kay Tisdall points out that there is a risk that Childhood Studies may be 'too insular - we do not necessarily talk 'back' to the broader disciplines' (Alanen et al., 2018: 134). For example, childhood researchers tend to publish in specialist childhood journals but less so in the main disciplinary journals, such as Children's Geographies instead of Area or Geoforum, or the Childhood journal instead of Sociology. As Alanen (2012) argues, it is important to mainstream within the broader disciplines otherwise childhood researchers are just preaching to the converted within Childhood Studies (see also Cook et al., 2018).

However, publishing routes are not necessarily straightforward when deciding where to publish and which audience to target. People directly interested in childhood research will be more likely to read an article in one of the specialist journals rather than a mainstream journal. Robert Vanderbeck's work on age and intergenerationality (published in Geography Compass) is a successful example of a mainstream paper being picked up and discussed by the relevant sub-discipline (Children's Geographies) but other authors have considered that the mainstream disciplinary route has missed the more specific audience of Childhood Studies, without necessarily having much impact upon the wider discipline. For example, Katz's research on children's work in rural Sudan was published in the Annals of the Association of American Geographers (Katz, 1991) but has had limited impact 
beyond the Geographies of Children and Youth. Similarly, my own work on birth order and children's work may have had greater reach with the most relevant target audience by not publishing in Work, Employment \& Society (Punch, 2001) or Sociology (Punch, 2003). Thus, work published in key disciplinary journals might be missed by the elements of Childhood Studies outwith that discipline.

To some extent our academic agency can be constrained as our choice of where to publish is structured (such as mainstream journals rejecting articles on Childhood Studies; or universities striving for the highest impact factors; or authors desiring to reach the most appropriate audience for further dialogue in the field). Ni Laoire recommends that we focus more on 'the disruptive impact that childhood studies can have in terms of challenging the adult-centrism of so many fields of research' (Alanen et al., 2018: 133). Nevertheless, as Tisdall continues in the same paper, there is a risk that Childhood Studies may be 'too insular - we do not necessarily talk 'back' to the broader disciplines,' (Alanen et al., 2018: 134).

\section{Politics of Childhood in Society}

The academic political project of Childhood Studies is different from the politics of childhood in society yet there are also aspects which overlap both arenas and have become stuck, especially in relation to children's rights and participation. There is not often a distinction made between children's agency and children's participation. The nuances of children's agency have only recently begun to be unpacked academically and perhaps more so in Majority World contexts.

Childhood Studies has always been a political project as it was about enabling children's voices to be heard and taken seriously; as well as ensuring that children's issues were on the political agenda (Tisdall, 2013). Berry Mayall (2006) emphasises that it is important to have simple messages around children's potential as competent social actors to make sure that children's rights and participation are on the relevant agendas and to raise awareness about children's issues, along with the importance of children having a say. A possible downside of this is that the academic discourse around children's agency has been too simplistic as it is a "much used but largely unexamined concept" (Mizen and Ofusu-Kusi 2013: 363) which can be vague and lack clarity.

This has resulted in many recent critiques, which indicate that there has been too strong a focus on agency within Childhood Studies (Hammersley, 2017; Prout, 2000; Tisdall and Punch, 2012). There has been a tendency to see children's agency everywhere (Oswell, 2013), yet there have not been many explicit definitions or conceptualisations of childhood agency. Children's agency has been extensively documented, but until recently this had not necessarily led to a problematisation of the concept in relation to the type of agency and outcome (Bluebond-Langner and Korbin 2007). Holloway et al. (2018) argue that there is 'a conceptual elision between the benefit of studying agency with the beneficial nature of agency,' which should lead to a 'move away from celebrations of young people's agency' (2018: 13).

Thus there has been a questioning of agency as "a contested and scrutinised concept" (Tisdall and Punch 2012: 256), with a shift from polarising children as either active or passive (Oswell 2013: 269) to seeing agency as a continuum which varies in different contexts and in relation to identities, emotions and power (Robson et al., 2007). In his recent critique of Childhood Studies, Hammersley remarks that:

... in the case of children, no less than with adults, there are issues about what people actually want to be free to do and what it is legitimate or desirable for them to be free to do. There are also questions about whether judgements about these matters should vary systematically according to whether the people concerned are children or adults, and how the boundaries of childhood ought to be defined. Declarations about the agency of children, of the kind to be 
found in much of the Childhood Studies literature, tend to obscure these issues, not least by reducing normative judgements to an apparently factual matter - the claim that children are 'active' or 'agentic'. (Hammersley, 2017: 121)

The interesting point to note is that, until very recently (such as Esser et al., 2016), explorations of children's agency, which had shed light on the complexities and nuances of their agency, had come from Majority World contexts. For example, Klocker's (2007) research with child domestic workers in Tanzania which illustrated the potential for children's agency to get 'thicker' or 'thinner' over time and space, and across their different relationships. Honwana's (2005) work with child soldiers in Mozambique explored the notion of tactical agency where vulnerability is about coping but is also an 'agency of the weak'. She argues that child soldiers have an in-between status where they are both child and adult, victim and perpetrator, guilty and innocent. Several authors comment on the way in which children's agency is often connected to moral judgements regarding perceptions of positive or negative agency. Bordonaro and Payne (2012) use the term ambiguous agency, which reflects the tensions involved when children's agency is perceived to go against the moral and social order of society. Whilst some Majority World contexts emphasise collective rather than individualised agency, there is also a recognition that children's agency is not autonomous, but relational (Jamieson and Milne, 2012) and often supported by adults (White and Choudhury, 2010).

Nevertheless, both Pells' (2012) work with children in Rwanda and Payne's (2012) research with child-headed households in Zambia reveal that despite the complexities which many children face in their everyday lives and the resilience and agency that they demonstrate in coping, there remains a disjuncture between the discourses of vulnerability/victimhood versus agency/participation. Both argue that children's agency continues to be treated tokenistically in practice by adults. One possible reason for this is that many adult practitioners still work within development models of childhood rather than embracing the notion of children as potentially competent social actors. This persistent gap between academic discourse and policy/practice may reflect that the academic discourse of Childhood Studies is not accessible enough (Mayall, 2006) or that it does not resonate enough with adults' views of children (Punch, 2016b) and that it needs to be understood from both adults' and children's perspectives (Hoang and Yeoh, 2014; Mannion and I'Anson, 2004). These studies of children's agency in different areas of the Majority World illustrate the interconnections of childhoods across both Majority and Minority World contexts, where adult practices may over focus on children's rights to protection rather than their rights to participation. The challenging processes of bridging theory, policy and practice can be similar in both Majority and Minority Worlds:

If the limitations of children's agency are acknowledged, and if vulnerability is accounted for, then perhaps the discourses of agency would be more likely to reflect the complexities of children's social status. (Punch, 2016b: 189)

Similarly, Oswell suggests that when considering children's agency there needs to be "a recognition of children's dependency" (Oswell, 2013: 280), and Childhood Studies should extend this further by explicitly bringing in the generational order when discussing childhood agency (Esser et al., 2016; Punch, 2016b). Oswell (2013) argues that part of the problem has been because childhood researchers have tended to focus more on either structure or agency instead of examining the relationship between the two (see also Holloway et al., 2018). The generational order is relevant as it is part of the structural context at both the level of adult-child relations as well as relations between children. An exploration of both intergenerationality (see Vanderbeck, 2007; Vanderbeck and Worth, 2015) as well as intragenerationality (such as Evans, 2012; Punch, 2016b) is useful when considering age relations across the life course. Locating children's agency within the generational order facilitates the bridging of the gap between academia and practice. Furthermore, Huijsmans (2016) argues that a relational approach, which encompasses processes of generationing, may help to bridge the gap between Childhood Studies and Development Studies. 
Esser et al.'s recent volume on Reconceptualising Agency and Childhood demonstrates the connections between the generational order and agency whilst also reminding us that: "Agency should not be conceived simply as individual action directed against the social structure" (2016: 291). They highlight that generational ordering enables an analysis of "the discourses and practices in which different positions, forms of authority, responsibilities and access to resources are distributed across the generations" (Esser et al., 2016: 7). Their volume illustrates the theoretical links between the concepts of agency and generational ordering, suggesting that both should be located in social relations and interdependency.

Ideas of interdependency are expanded further by Holloway et al. (2018) who argue that space and time should be incorporated more when examining children's agency. In particular, they suggest that the concept of 'encounter' can be used as a way of connecting human agency and materialities or assemblages:

Specifically, we argue that the politicized focus on the making of difference, and the insistence that the site of encounter is linked to spaces and regimes of power beyond the event, provides a conceptual space where we can explore the contingent, embodied, connected and specifically human agency of subjects whose actions may in part be purposeful and rational, and driven by affect and beyond-conscious motivations. (Holloway et al., 2018: 14)

They also encourage the combining of 'being and becoming' approaches to childhood where 'the embodied subject of agency and stretched notions of time moves us to emphasize that children are "biosocial beings and becomings' (Holloway et al., 2018: 14). Their work illustrates the importance of considering the ways in which biosocial agency is played out both across the lifecourse as well as across generations.

\section{Lack of Engagement with the Generational Order}

A key barrier to embedding the generational order was that the concept was criticised from early on in Childhood Studies before it had been explored empirically in a range of contexts. It could be argued that the generational order was swept aside too quickly. Alanen and Mayall (2001) developed the use of the term 'generationing' as a structural feature of child-adult interactions, which include 'childing' and 'adulting' practices. They argued that childhood is part of a wider generational order that is constituted by 'a complex set of social processes through which people become (are constructed as) 'children' while other people become (are constructed as) 'adults," (Alanen, 2001: 20-21). Processes of generationing mean that "one position (such as the parental position) cannot exist without the other (child) position” (Alanen, 2001: 19).

This is similar to the concept of intergenerationality where one's generational status shapes the nature of child-adult relations (Vanderbeck and Worth, 2015). For Alanen and Mayall (2001) child-parent relations are developed on the understanding that childhood is relational with parenthood. Yet their theoretical ideas have not often been engaged with in an explicit way. The generational order is at times referred to, but within the UK at least, it has been less developed theoretically than the gender order (Punch and Vanderbeck, 2018). Alanen (2001: 21) states that it is through childing and adulting practices that 'the two generational categories of children and adults are recurrently produced and therefore they stand in relations of connection and interaction, of interdependence'. This fits with more recent work on intergenerationality where the generational positions can be explored as sites and spaces in which conflict, cooperation and change are played out and negotiated (Vanderbeck and Worth, 2015). 
In their recent edited book: Feminism and the Politics of Childhood: Friends or Foes?, Rosen and Twamley discuss the commonalities and conflicts between the fields of Childhood and Women's Studies which are 'generally depicted as being very separate political projects, with contradictory attributions of the relative 'success' of each' (2018: 16). For example, one contributor Zehavi considers that Childhood Studies has a long way to go compared with feminism in terms of being a revolutionary political project. Whilst Thomson and Baraitser consider that the visibility of childhood journals and degree programmes is greater when compared with Women's Studies. However, it could be argued that the lack of specialist journals and separate university programmes may mean that Women's Studies has achieved greater integration into mainstream disciplines compared with Childhood Studies. The limited mainstreaming of Childhood Studies compared with Gender Studies is reflected in research funding requirements in the UK. For example, research council funding, such as the Global Challenges Research Fund, would not grant an award to a project that has not considered gender relations but issues relating to age and generation would not hold the same weight. Children and young people's perspectives are not mainstreamed into development projects in the same way that women and men's views are routinely taken into account (see Huijsmans, 2016; Punch, 2016b).

There are three possible reasons as to why the generational order has been overlooked in Childhood Studies. Firstly, the early critiques considered that the generational order was too stuck on the childadult dichotomy. During conferences in the early 1990s when Childhood Studies was being established, Leena Alanen and Berry Mayall put forward their ideas on processes of generationing but their arguments were quickly criticised by others suggesting different ways forward. For example, Nick Lee (2001) argued that there are unhelpful divisions between mature adults and immature children, and such boundaries, along with dualisms of nature and culture, should be broken down. Alan Prout pointed to the importance of actor network theory as a way of breaking down the distinction "between culture and nature by focusing on the network of mediation between them" (2000: 14). Using Latour's work, he argued that childhoods are understood in relation to symbolic and material culture:

“...made up through a wide variety of shifting associations (and dissociations) between human and non-human entities. Indeed, so ubiquitous are associations between humans and the rest of the material world that all entities are to be seen as hybrids" (Prout, 2000: 14)

David Oswell (2013) similarly criticised Alanen and Mayall's (2001) theoretical framework as being too stuck on the child-adult dichotomy, also preferring actor network theory or assemblage theory: where assemblage, network, apparatus and infrastructure are fore fronted rather than 'generational' differences. Whilst some of these theoretical ideas took a while to emerge in publications and have made a significant contribution to the field, these theorists had been instrumental in shifting the focus away from the generational order.

Thus a key critique of the generational order focused on the child-adult dichotomy, but Hammersley (2017: 116-117) points out the inconsistencies and tensions within Childhood Studies that partly result because "differences between children and adults are played down [...] but this does not undercut the main point that 'not yet adult' is a major component of what the term 'child' must mean." He also emphasises that Childhood Studies suggests that children's lives must be studied within the wider socio-economic context. This must therefore be "to a large extent in the context of adult cultural practices and forms of social organisation" (2017: 116-117), thereby reinforcing the need for locating childhood research within the generational order.

Perhaps if Childhood Studies had not been so quick to move on to other theoretical ideas without unpacking the generational order further, our understanding and use of it may have been adapted so that it was not perceived as a static and inflexible structure. For example, it would be more appropriate to refer to 'generational orderings' in the plural to reflect that the generational order can take shape 
in a variety of manners and can also be performed in different ways. Furthermore, the notion of childing and adulting practices could have been developed via an empirical exploration of what this may mean in different contexts.

There could have been more parallels between the generational order and the gender order in relation to the way that theorising around the gender order changed over the years, such as moving from a focus on difference to a relational focus (Connell, 2002). However, in Childhood Studies the generational order was perhaps rejected too promptly as a plausible avenue, so the concept did not have a chance to emerge in the same way that the gender order was critiqued and developed, rather than disregarded as not useful. There has been a tendency to over critique what Alanen and Mayall (2001) were trying to establish, by saying that other aspects of social life are more important so generation and age should not always be at the centre of our analysis within Childhood Studies. It may be the case that the generational order is not always central, but Alanen and Mayall (2001) argue that it is always present. As Qvortrup argues:

The child-adult contrast is a structural distinction, in the sense that it gives structure to a wide variety of superficially different situations. This structural distinction between childhood, adulthood and old age is a generational distinction and my theseis is that without a generational perspective we do not need social studies of childhood. (Cook et al., 2018; 10-11)

The generational order is a social structural category that may not always be the most important aspect of children's or adults' lives but it is always there, albeit in different ways. Thus the second reason for becoming stuck in relation to our understanding of the generational order is because it has not been investigated empirically in an extensive way (exceptions include Alanen and Mayall, 2001; Esser et al., 2016; Horton, 2016; Huijsmans, 2016; Mayall, 2002; Mayall and Zeiher, 2003; Punch, 2005). The generational order has tended to be taken-for-granted as a starting point but not really questioned, challenged and extended. Mannion and I'Anson point out that Qvortrup's (1994; 2009) theorising about the structural relationship between the natures of childhood and adulthood were too often taken-for-granted as 'an almost unquestioned 'fact'" (2004: 314). Processes of generationing as well as childing and adulting practices have rarely been grappled with as an empirical question. As outlined above, some social theorists in Childhood Studies were quick to dismiss the generational order as being a singular order instead of a diversity of orderings. Hence the ways in which generational structurings are played out have only received limited empirical attention which, until recently (Esser et al., 2016; Huijsmans, 2016; Vanderbeck and Worth, 2015), has been mainly by Alanen and Mayall in their own work.

The third area that has been somewhat neglected are processes of intra-generationing which are also integral to generational orderings. Thus the generational order is not only about a binary between childhood and adulthood but should also include intra-generational relations. When considering concepts like agency and power, the greatest focus tends to be centred on vertical adult-child relations rather than lateral relations between children (Punch and Vanderbeck, 2018). For example, Ruth Evans' (2012) work in different African contexts demonstrates that intra-generational relations are often overlooked in relation to caring. When we are thinking explicitly about the generational order, the importance of age, birth order and sibling composition should be considered as intra-generational factors which may shape the generational orderings. For example, within household divisions of labour in both Majority World and Minority World contexts, age and birth order can at times be more important than gender for children's work roles (Punch, 2001). In a project on sibling relationships in Scotland with families with three children the ways in which agency and power between siblings was played out was quite different from that between parents and children (Punch, 2005). Thus, the generationing of power means that parental and sibling power relations are potentially shaped in different ways partly because of age and birth order. Yet when we consider intra-generational 
relations during childhood, we tend to examine issues of gender, age, ethnicity and class but still not birth order. Sociologically the birth order tends to have been quite neglected as a social variable.

\section{Developing Childhood Studies}

There have been recent discussions about the need to 'go beyond' Childhood Studies (Kraftl, 2013) or to 'decenter childhood' (Spyrou, 2017). There is certainly an implication that Childhood Studies is lacking in some way (or 'stuck' as this paper is referring to it). Nevertheless, before moving beyond the field, more could be done to develop existing theoretical and conceptual frameworks. As this paper argues, generational orderings could be explored in a more nuanced and less fixed manner; unpacking the dynamic processes of generationing both within and across the generations. Similarly, Esser et al. (2016) argue that a relational lens offers a broader way of discussing childhood concerns.

It is recognised that it is generally no longer appropriate to focus only on children or children's perspectives (Mannion and I'Anson, 2004; Spyrou, 2017), as wider generational relations should be considered in research with children about their lives (Vanderbeck and Worth, 2015). Yet as mentioned, Childhood Studies has perhaps not delivered in the same way that Gender Studies managed to achieve over a similar time period and there is some disappointment with progress (both academically and in practice/policy). One possible reason is because there has tended to be a parallel discussion of theory and empirical work; perhaps more so in Childhood Studies than in other fields, such as Gender Studies (see Rosen and Twamley, 2018)? Furthermore, there seems to be limited dialogue between theorising and empirical work (such as the plethora of empirical studies demonstrating that children are social actors, without unpacking the concept of agency).

Adrian James' paper (2010): “Competition or Integration? The Next Step in Childhood Studies?" calls for more theoretical integration in Childhood Studies. He refers to childhood researchers often taking a macro or a micro approach to understandings of childhood(s), suggesting that they might be combined more frequently. His arguments about integration or competition could also apply to the sub-disciplines of Childhood Studies, which at times may be unhelpfully in competition with each other rather than better integrated (Punch, 2016a). For example, children's geographers often complain that sociologists of childhood do not tend to reference their work as much as the other way round. Similarly, sociologists complain that geographers claim that sociologists do not address issues of space and place adequately. Rather than internally competing or discussing within sub-disciplinary boundaries, a wider focus may have expanded the relevance of Childhood Studies for global debates, as Nieuwenhuys suggests:

... perhaps we have not been attentive enough to the wider impact of children's rights on scholarship in general and have failed to appreciate that, as we were staking out the field, others were also occupying territory. (Cook et al., 2018: 10)

There are tensions and competition between academic disciplines within Childhood Studies which is meant to be an interdisciplinary field. Morrow points out that 'childhood studies could make much greater effort to learn from and speak to other disciplines in a conciliatory manner.' (Cook et al., 2018: 15). The feasibility of interdisciplinarity within Childhood Studies has been questionable, given that up until now most disciplines have worked separately in relation to exploring children's lives or perhaps in a multi-disciplinary way, bringing together disciplinary perspectives alongside each other rather than in a fully integrated manner (Thorne, 2007). One example is Ryan's (2011) discussion of a 'new wave' of Childhood Studies where he advocated biosocial approaches and the need to work in more interdisciplinary ways. Yet there was no discussion of the work of the anthropologist, Catherine Panterbrick, in this area in the 1990s (Panterbrick, 1998) nor of Aitken's (2001) work on the body and embodiment nor of the special issue of Children's Geographies on the body and childhood (Colls and Hörschelmann, 2009). 
There are many reasons why effective interdisciplinary working is challenging to achieve in practice. Interdisciplinarity sounds ideal in many ways, but similar to translating other useful concepts into reality, such as 'participation' or 'rights', in practice it can be difficult to achieve meaningful outcomes because of the constraints of resources, time, language, and competing agendas (see Hansen et al., 2018; Punch, 2016a). It is an interesting question to consider how Childhood Studies might deliver in relation to interdisciplinarity given that some of the similar sub-fields, Geography, Sociology, Anthropology have not necessarily managed to speak to each other very often. Even more challenging might be how some of the other sub-disciplines might work together where differences in approach may be more marked (such as Psychology, Health, Education, Social Work or History).

Nevertheless, it is likely that, similar to most academic fields, Childhood Studies will move more towards integrated interdisciplinary approaches in the future. Kraftl (2013) has been optimistic about the potential for interdisciplinary work in Childhood Studies, and his current project on food, water and energy bridges the divide between natural and social sciences. As Kay Tisdall points out, Childhood Studies needs to move 'beyond the 'friendly' disciplines to those that are more challenging' (Alanen et al., 2018: 134). A further illustration is the lack of dialogue between literatures from different world areas: childhood researchers working on Minority World childhoods rarely draw upon conceptual or theoretical thinking developed within Majority World contexts, even though lessons could be learnt, applied or adapted (Hanson et al., 2018).

\section{Majority World Children Stuck at the Margins?}

It is a little paradoxical that the majority of the world's children tend to be marginalised in Childhood Studies (Cook et al., 2018). Most theories and concepts in Childhood Studies tend to be developed in Minority World and used in the Majority World but not vice-versa (Hanson et al., 2018; Punch, 2016a). This is perhaps not surprising given that it is a general challenge for the development of social theory which, as Bhambra (2014) argues, can be Eurocentric and needs to engage more with the past and present realities of globalisation. James (2010) suggests that childhoods in the Majority World are perhaps too different for there to be an effective comparison. Yet Hecht's (1998) work on Brazilian childhoods reminds us that class is often a central factor. He argues that the independent, nurturing childhoods of poor children from the Majority World are likely to have more in common with the childhoods of the working classes in the Minority World than with the protected, nurtured childhoods of middle-class children from their own country. In a globalised world, is it acceptable or appropriate for Minority World assumptions about children's rights, participation and agency to dominate the academic and policy agendas?

Boyden (1997) raised the issue of the global model of childhood dominated by Minority World understandings of childhood as problematic twenty years ago, as it implies there is a norm for certain aspects of children's lives (see also Kaufman and Rizzini, 2002). As Twum-Danso Imoh points out, it is inappropriate if Minority World norms are imposed in such a way that: "In the process, Southern childhoods and childrearing practices relating to feeding and play are pathologized, deemed as deficient and in need of 'fixing'." (2016: 191). Similarly Kesby et al. (2006) argue that 'other childhoods' should be conceptualised as they are rather than in terms of what they are not. It is ironic that in quantitative terms, particularly in relation to combining work and school, the norm is the Majority World experience of childhood (see Punch, 2003). There are a range of resource, language and other issues which affect the development of social theories (the discussion of which remains outside the scope of this paper - see Bhambra, 2014; Cook et al., 2018; Punch, 2016a), but there are implications for the production of knowledge within Childhood Studies if most is driven from the Minority World (Hanson et al., 2018). Lessons that are learnt tend to be heavily in one direction yet, as this paper has shown, there are examples of how mutual learning could take place in more reciprocal ways. 


\section{Conclusion}

This paper has referred to some examples of the possibilities for cross-world learning in relation to the nuances of children's agency. A similar exploration of the intricacies and complexities of the generational order in some Majority World settings might also enable a rethinking of interdependent generational relationships in other contexts. For example, the concept of negotiated and constrained interdependencies within and across generations allows for the dynamic and contingent nature of children's agency situated in a specific social and cultural context (Punch, 2015a). A framework of generational orderings, which encompass both enabling and constraining processes, can reveal the positive and negative aspects of the relational approaches to children's agency and interdependencies from generational perspectives (Esser et al., 2016).

Such examples illustrate the potential for dialogue across Majority and Minority Worlds, demonstrating how the Minority World can learn from concepts developed in relation to Majority World childhoods (Punch 2016a; Twum-Danso Imoh et al., Forthcoming 2018). The development of theories and concepts of Childhood Studies could be enhanced if more comparative work was conducted across the Majority and Minority Worlds, as direct comparisons up until now have been extremely rare. More cross-world dialogue would enhance reciprocal learning processes rather than assuming that the study of Majority World childhoods is not relevant to other contexts. In a globalising world, as we face a range of global challenges, it is time for that to change.

The starting point of this paper was that Childhood Studies is generally a multi-disciplinary field, which has potential for interdisciplinarity and greater dialogue between sub-disciplines and contexts as well as with those outside academia. Whilst acknowledging the diversity of children's childhoods and limitations of direct comparisons, there is room for exploration and dialogue across world contexts of some broad similarities and differences of Majority World and Minority World childhoods (Punch, 2015b). Despite being in a new 'wave' (Ryan, 2011) with a new generation of researchers, Childhood Studies seems to be stuck from moving forward conceptually. The politics of Childhood Studies leads us to be stuck in sub-disciplines rather than working in a more interdisciplinary way. The politics of childhood in society have moved forward in terms of children's rights and participation, yet the theoretical development of related concepts also appears to be stuck. A greater engagement with cross-world dialogue could lead to more nuanced and complex understandings of childhoods and generational orderings.

This paper has raised questions as to why Childhood Studies has not achieved as much as Gender Studies over a similar time period. Thirty years after Gender Studies emerged as a sub-discipline, gender was recognised as a key social variable, mainstreamed in social science research and funding applications. As this paper has suggested, perhaps one of the reasons why age has not been mainstreamed more, is because there was an early shift away from the 'generational order' as it became criticised early on rather than really grappled with and extended or adapted. By not developing the generational order in a similar manner to the way the gender order was developed over time, the messages about the importance of generation and age as key social variables have become diluted. This paper suggests that 'generational orderings' offer a dynamic way for Geography, Sociology and Development Studies to engage with processes of generationing that span across both intergenerational and intragenerational relations.

\section{References}

Aitken, S. (2001) Geographies of Young People, London: Routledge. 
Alanen, L. (2009) 'Generational Order', in Qvortrup, J., Cosaro, W. and Honig, M-S. (eds) The Palgrave Handbook of Childhood Studies, Basingstoke: Palgrave Macmillan, pp.159-174.

Alanen, L. (2012) 'Disciplinarity, Interdisciplinarity and Childhood Studies', Childhood, 19(4):419422.

Alanen, L. and Mayall, B. (2001) (eds) Conceptualising Child-Adult Relations, London: RoutledgeFalmer

Alanen, L., Baraldi, C., de Coninck-Smith, N., Ni Laoire, C. and Tisdall, K. (2018) 'Crossdisciplinary Conversation in Childhood Studies: Views, Hopes, Experiences, Reflections', Childhood, 25(2): 127-141.

Bhambra, G. (2014) Connected Sociologies, Oxford: Bloomsbury.

Bluebond-Langner, M. and Korbin, J. (2007) 'Challenges and Opportunities in the Anthropology of Childhoods: An Introduction to "Children, Childhoods, and Childhood Studies," American Anthropologist, 109 (2): 241-246.

Bordonaro, L. and Payne, R. (2012) 'Ambiguous Agency: Critical Perspectives on Social Interventions with Children and Youth in Africa', Children's Geographies, 10 (4): 365-372.

Boyden, J. (1997) 'Childhood and the Policy Makers: A Comparative Perspective on the Globalization of Childhood', in James, A. and Prout, A. (eds.) (1990) Constructing and Reconstructing Childhood: Contemporary Issues in the Sociological Study of Childhood. London: The Falmer Press, p.184-215.

Chawla, L. (ed.) (2002) Growing Up in an Urbanising World, London: Earthscan Publications.

Colls, R. and Hörschelmann, K. (2009) 'The Geographies of Children's and Young People's Bodies', Children's Geographies, 7(1): 1-6.

Connell, R.W. (2002) Gender, Cambridge: Polity Press.

Cook, D., Frones, I., Rizzini, I., Qvortrup, J., Nieuwenhuys, O. and Morrow, V. (2018) 'Past, Present and Futures of Childhood Studies,' Childhood, 25(1): 6-18.

Cribari-Assali, C. (2018) 'Cross-Cultural Research on Children's Well-Being and the Generational Approach', in Punch, S. and Vanderbeck, R. (eds) Families, Intergenerationality, and Peer Group Relations, Vol. 5 of Skelton, T. (editor-in-chief) Springer Major Reference Work in Geographies of Children and Young People. Singapore: Springer.

Esser, F., Baader, M., Betz, T. and Hungerland, E. (2016) (eds) Reconceptualising Agency and Childhood: New Perspectives in Childhood Studies, London: Routledge.

Evans, R. (2012) 'Sibling Caringscapes: Time-space Practices of Caring within Youth-headed Households in Tanzania and Uganda', Geoforum, 43(4): 824-835

Hammersley, M. (2017) ‘Childhood Studies: A Sustainable Paradigm?’ Childhood, 24(1): 113-127.

Hanson, K., Abebe, T., Aitken, S.C., Balagopalan, S. and Punch, S. (2018) 'Global/Local' Research on Children and Childhood in a 'Global Society', Childhood, 25(3). 
Hecht, T. (1998) At Home in the Street: Street Children of Northeast Brazil. Cambridge: Cambridge University Press.

Hoang, L. and Yeoh, B. (2014) 'Children's Agency and its Contradictions in the Context of Transnational Labour Migration from Vietnam’, Global Networks, 15(2) DOI: 10.1111/glob.12057.

Holloway, S., Holt, L. and Mills, S. (2018) 'Questions of Agency: Capacity, Subjectivity, Spatiality and Temporality', Progress in Human Geography, available at:

http://journals.sagepub.com/doi/full/10.1177/0309132518757654

Honwana, A. (2005) 'Innocent and Guilty. Child Soldiers as Interstitial and Tactial Agents', in A. Honwana and F. de Boeck (eds) Makers and Breakers, Oxford: James Currey, pp.31-52.

Horton, P. (2016) 'Generationing School Bullying: Age-based Power Relations, the Hidden Curriculum and Bullying in Northern Vietnamese Schools', in Huijsmans, R. (ed.) Generationing Development: A Relational Approach to Children, Youth and Development, Basingstoke: Palgrave Macmillan, p.127-150.

Huijsmans, R. (2016) Generationing Development: A Relational Approach to Children, Youth and Development, Basingstoke: Palgrave Macmillan.

James, A. (2010) 'Competition or Integration? The next step in Childhood Studies?' Childhood, 17 (4), 485-499.

James, A. and Prout, A. (eds.) (1990) Constructing and Reconstructing Childhood: Contemporary Issues in the Sociological Study of Childhood. London: The Falmer Press.

Jamieson, L. and Milne, S. (2012) 'Children and Young People's Relationships, Relational Processes and Social Change: Reading Across Worlds,' Children's Geographies, 10(3): 265-278.

Jeffrey, C. and Dyson, J. (2008) Telling Young Lives: Portraits of Global Youth, Temple University Press, Philadelphia, PA.

Katz, C. (2004) Growing up Global: Economic Restructuring and Children's Everyday Lives, Minnesota: University of Minnesota.

Katz, C. (1991) 'Sow What you Know: the Struggle for Social Reproduction in Rural Sudan'. Annals of the Association of American Geographers 81(3):488-514.

Kaufman, N.H. and Rizzini, I. (2002) Globalization and Children: Exploring Potentials for Enhancing Opportunities in the Lives of Children and Youth. London: Plenum Publishers.

Kesby, M., Gwanzura-Ottemoller, F. and Chizororo, M. (2006) Theorizing other, "other childhoods": issues emerging from work on HIV in urban and rural Zimbabwe. Children's Geographies, 4 (2), 185-202.

Klocker, N. (2007) An example of thin agency: child domestic workers in Tanzania. In: R. Panelli, S. Punch and E. Robson, eds. Global Perspectives on Rural Childhood and Youth: Young Rural Lives. London: Routledge, pp.81-148. 
Kraftl, P. (2013) 'Beyond 'Voice', Beyond 'Agency', Beyond 'Politics'? Hybrid Childhoods and some Critical Reflections on Children's Emotional Geographies,' Emotion, Space and Society, 9: 13-23.

Lee, N. (2001) Childhood and Society, Buckingham: Open University Press.

Mannion, G. and I'Anson, J. (2004) 'Beyond the Disneyesque: Children's Participation, Spatiality and Adult-Child Relations’, Childhood: 11(3): 303-318.

Mayall, B. (2006) 'Values and Assumptions Underpinning Policy for Children and Young People in England,' Children's Geographies, 4(1): 9-18.

Mayall, B. and Zeiher, H. (2003) Childhood in Generational Perspective, London: Institute of Education, University of London.

Mayall, B. (2002) Towards a Sociology for Childhood, Buckingham: Open University Press.

Mizen, P. and Ofusu-Kusi, Y. (2013) ;Agency as Vulnerability: Accounting for Children's Movement to the Streets of Accra', The Sociological Review, 61: 363-382.

Oswell, D. (2013) The Agency of Children: From Family to Global Human Rights, Cambridge: Cambridge University Press.

Panelli, R., Punch, S. and Robson, E. (2007) (eds) Global Perspectives on Rural Childhood and Youth: Young Rural Lives, London: Routledge.

Panterbrick, C. (1998) Biosocial Perspectives on Children, Cambridge: Cambridge University Press.

Payne, R. (2012) 'Extraordinary survivors' o ‘ordinary lives'? Embracing 'everyday agency' in social interventions with child-headed households in Zambia,' Children's Geographies, 10(4): 399412.

Pells, K. (2012) “Rights are everything we don't have': Clashing conceptions of vulnerability and agency in the daily lives of Rwandan children and youth, Children's Geographies, 10(4):427-440.

Phoenix, A., Boddy, J., Walker, C. and Vennam, A. (2017) Environment in the Lives of Children and Families: Perspectives from India and the UK, Bristol: Policy Press.

Prout, A. (2000) 'Childhood Bodies: Construction, Agency and Hybridity', in Prout, A. (ed.) The Body, Childhood and Society, Basingstoke: Macmillan Press, p.1-18.

Punch, S. (2016a) 'Cross-world and Cross-disciplinary Dialogue: A More Integrated, Global Approach to Childhood Studies', Global Studies of Childhood, 6(3): 352-364.

Punch, S. (2016b) 'Exploring Children's Agency across Majority and Minority World Contexts', in Esser, F., Baader, M., Betz, T. and Hungerland, E. (eds) Reconceptualising Agency and Childhood: New Perspectives in Childhood Studies, London: Routledge, p.183-196.

Punch, S. (2015a) 'Youth Transitions and Migration: Negotiated and Constrained Interdependencies within and across Generations', Journal of Youth Studies, 18(2): 262-276. 
Punch, S. (2015b) 'Possibilities for Learning between Childhoods and Youth in the Minority and Majority Worlds: Youth Transitions as an Example of Cross-world Dialogue,' in Wyn, J. and Cahill, H. (eds) Handbook of Children and Young Adulthood, Singapore: Springer.

Punch, S. (2005) 'The Generationing of Power: A Comparison of Child-Parent and Sibling Relations in Scotland', Sociological Studies of Children and Youth, Volume 10: 169-188.

Punch, S. (2003) 'Childhoods in the Majority World: Miniature Adults or Tribal Children?' Sociology, 37 (2): 277-295.

Punch, S. (2001) 'Household Division of Labour: Generation, Gender, Age, Birth Order and Sibling Composition,' Work, Employment \& Society, 15 (4): 803-823.

Punch, S. and Tisdall, K. (2012) 'Exploring Children and Young People's Relationships Across Majority and Minority Worlds', Children's Geographies, 10(3): 241-248.

Punch, S. and Tisdall, K. (eds) (2014) Children and Young People's Relationships: Learning Across Majority and Minority Worlds, London: Routledge.

Punch, S. and Vanderbeck, R. (2018) 'Introduction: Families, Intergenerationality and Peer Group Relations', in Punch, S. and Vanderbeck, R. (eds) Families, Intergenerationality, and Peer Group Relations, Vol. 5 of Skelton, T. (editor-in-chief) Springer Major Reference Work in Geographies of Children and Young People. Singapore: Springer.

Qvortrup, J. (1994) 'Introduction', in Qvortrup, J., Bardy, M., Sgritta, G. And Wintersberger, H. (eds) Childhood Matters, Aldershot: Avebury, pp.1-24.

Qvortrup, J. (2009) 'Childhood as a Structural Form', in Qvortrup, J., Cosaro, W. and Honig, M-S. (eds) The Palgrave Handbook of Childhood Studies, Basingstoke: Palgrave Macmillan, pp.21-33.

Robson, E., Bell, S. and Klocker, N. (2007) Conceptualizing Agency in the Lives and Actions of Rural Young People', in: R. Panelli, S. Punch and E. Robson, eds. Global Perspectives on Rural Childhood and Youth: Young Rural Lives, London: Routledge, pp.135-148.

Rosen, R. and Twamley, K. (eds) (2018) Feminism and the Politics of Childhood: Friends or Foes?, London: UCL Press.

Ryan, K. (2011) 'The New Wave of Childhood Studies: Breaking the grip of Bio-social Dualism', Childhood, 19(4): 439-452.

Spyrou, S. (2017) ‘Time to Decenter Childhood?' Childhood, 24(4): 433-437.

Thomson, R. and Baraitser, L. (2018) 'Thinking through Childhood and Maternal Studies', in Rosen, R. and Twamley, K. (eds) Feminism and the Politics of Childhood: Friends or Foes?, London: UCL Press, pp66-81.

Thorne, B. (2007) 'Editorial: Crafting the Interdisciplinary Field of Childhood Studies', Childhood, 14 (2), 147-152.

Tisdall, K, (2013) 'The Transformation of Participation: Exploring the Potential of 'Transformative Participation' for Theory and Practice around Children and Young People's Participation,' Global Studies of Childhood, 3(2):183-193. 
Tisdall, K. and Punch, S. (2012) 'Not so 'new'? Looking Critically at Childhood Studies', Children's Geographies, 10(3): 249-264.

Twum-Danso Imoh, A. O. (2016). From the Singular to the Plural: Exploring Diversities in Contemporary Childhoods in sub-Saharan Africa. Childhood, 23(3), 455.

Twum-Danso Imoh, A, Bourdillon M, Meischner, S (forthcoming 2018), 'Introduction' in TwumDanso Imoh, A, Bourdillon, M and Meischner (eds), Global Childhoods beyond the North-South Divide, New York and London: Palgrave.

Vanderbeck, R.M. (2007) 'Intergenerational Geographies: Age Relations, Segregation and Reengagements', Geography Compass, 1 (2): 200-221.

Vanderbeck, R. and Worth, N. (2015)'Introduction', in Vanderbeck, R. and Worth, N (eds) Intergenerational Space, London: Routledge, pp.1-14.

White, S. and Choudhury, S. (2010) 'Children's Participation in Bangladesh: Issues of Agency and Structures of Violence,' in: B. Percy-Smith and N. Thomas, eds. A Handbook of Children and Young People's Participation, London: Routledge, pp.39-50.

Zehavi, O. (2018) 'Becoming-woman, Becoming-child: A Joint Political Programme,' in Rosen, R. and Twamley, K. (eds) Feminism and the Politics of Childhood: Friends or Foes?, London: UCL Press, pp.241-256. 